\title{
Effects of naloxone on the oestradiol-induced LH surge and cortisol release in transported cows
}

\author{
A. S. Nanda, W. R. Ward and H. Dobson \\ Department of Veterinary Clinical Science, University of Liverpool Veterinary Field Station, \\ Chester High Road, Neston, South Wirral, L64 7TE, UK
}

\begin{abstract}
Summary. Four control cows released a normal LH surge in response to $1 \mathrm{mg}$ oestradiol benzoate i.m. Compared to controls, $30 \mathrm{~min}$ transport of 5 cows $16-18 \mathrm{~h}$ after oestradiol significantly delayed the onset $(P<0.05)$, suppressed the amplitude $(P<0.01)$ and reduced the total $\mathrm{LH}$ release $(P<0.001)$ in 4 cows and totally blocked the surge in the 5th cow. Just before the onset of transport, 5 cows were given $250 \mathrm{mg}$ naloxone i.v. In 3 cows, the LH surge was delayed and reduced in amplitude and duration and was totally blocked in the other two, i.e. naloxone did not avert the detrimental effects of transport.

Transport stimulated cortisol release in cows. Cows given naloxone + transport released significantly more $(P<0.001)$ cortisol than did those subjected to transport alone. In conclusion, naloxone appeared to have further stimulated the hypothalamopituitary-adrenal axis of cows under stress.
\end{abstract}

Keywords: transport; LH; cortisol; naloxone; opioids; cows

\section{Introduction}

The preovulatory LH surge is a vital component of the reproductive process in animals. Defective LH surges have been implicated in various ovulatory disturbances in cattle (Nadaraja \& Hansel, 1976; Kesler et al., 1979; Refsal et al., 1988), and events such as suckling (Radford et al., 1978; Short et al., 1979) and transport (Nanda et al., 1988a) can delay and/or attenuate preovulatory LH surges induced in cattle by oestradiol. In response to a variety of acute stressors, cortisol is secreted (Echternkamp, 1984; Dobson, 1987) simultaneously with $\beta$-endorphin, an endogenous opioid peptide (Guillemin et al., 1977). Treatment with opioid agonists blocked spontaneous or oestradiol-induced LH surges in rats (Ieiri et al., 1980), sheep (Brooks et al., 1986) and cattle (Nanda et al., 1988b) and this could be prevented by simultaneous treatment with naloxone or other opioid antagonists. Naloxone alone on the morning of pro-oestrus advanced the LH surge in rats (Allen \& Kalra, 1986). A decline in portal blood concentrations of $\beta$-endorphin occurs at the time of the preovulatory $\mathrm{LH}$ surge in rats (Sarkar \& Yen, 1985) and sheep (Bernard et al., 1988). The LH inhibition of $\beta$-endorphin manifested during the period preceding hypothalamic GnRH and plasma LH surges is removed at the time of preovulatory LH surge (Bernard et al., 1988).

From the above evidence, in this study we tested the hypothesis that opioids are involved with stress-induced aberrations in the LH surge and that naloxone would avert the detrimental effects of 30 min transport at the expected onset of an oestradiol-induced LH surge in early post-partum cows (Nanda et al., 1988a).

\section{Materials and Methods}

Animals. Nine lactating Holstein-Friesian dairy cows within 1 month post partum were housed in groups of 4 or 5 in tied stanchions and fed standard dairy concentrates, and hay and water ad libitum. Ovarian activity was monitored weekly by palpation per rectum and by measurement of plasma progesterone concentration in tail vein blood. 
Treatments. Cows were given $1 \mathrm{mg}$ oestradiol benzoate (Intervet Laboratories Ltd, Cambridge, UK) in $2 \mathrm{ml}$ arachis oil i.m. An indwelling jugular vein catheter was inserted a day before frequent blood sampling. When applicable, the cows were transported around the time of the expected onset of the LH surge, i.e. $16-18 \mathrm{~h}$ after oestradiol. The cows were transported either individually or in pairs in a truck that had $3 \times 1$ metres of space for each cow. Each journey lasted for $25-30 \mathrm{~min}$ along metalled country roads.

Four cows served as controls and were given oestradiol alone. Another group of 5 cows was transported $16-18 \mathrm{~h}$ after oestradiol. On another occasion, the same 5 cows received $250 \mathrm{mg}$ naloxone hydrochloride (Sigma, St Louis, MO, USA) in $10 \mathrm{ml} 0.9 \%(\mathrm{w} / \mathrm{v})$ sodium chloride solution injected through the jugular venous catheter immediately before the journey. The transport and the transport + naloxone treatments were given in a crossover design with an interval of 1 week. Heparinized blood samples were collected at the time of oestradiol administration, every $2 \mathrm{~h}$ from 16 to $32 \mathrm{~h}$ after oestradiol to characterize the LH surge, and every $15 \mathrm{~min}$ from $1 \mathrm{~h}$ before to $2.5 \mathrm{~h}$ after each journey, to assess changes in cortisol concentrations. The blood samples were centrifuged immediately for $10 \mathrm{~min}$ at $1000 \mathrm{~g}$ and plasma stored at $-15^{\circ} \mathrm{C}$ until analysis.

Hormone analyses. Plasma progesterone, $\mathrm{LH}$ and cortisol were analysed by radioimmunoassays described elsewhere (Kanchev et al., 1976; Alam \& Dobson, 1986; Alam et al., 1986; respectively). Intra- and inter-assay coefficients of variation were $<10 \%$ except for $14.7 \%$ inter-assay variation for cortisol. Assay sensitivity, defined as twice the standard deviation above the buffer control, was $0.015 \mathrm{ng} / \mathrm{ml}$ for progesterone, $0.5 \mathrm{ng} / \mathrm{ml}$ for $\mathrm{LH}$ and $0.1 \mathrm{ng} / \mathrm{ml}$ for cortisol.

Statistical analysis. An increase in $\mathrm{LH}$ values to $\geqslant 10 \mathrm{ng} / \mathrm{ml}$ in 2 consecutive samples collected $2 \mathrm{~h}$ apart was considered as an $\mathrm{LH}$ surge. The first rise to $\geqslant 10 \mathrm{ng} / \mathrm{ml}$ was considered as the onset of the surge. The time of onset, the duration, the peak value and the area under the curve measured with a planimeter (arbitrary units) in treated cows were compared by Student's $t$ tests with corresponding values in control cows. The comparison between 2 treatment groups was made by a paired Student's $t$ test. The maximum rise above the pre-treatment cortisol concentration and the areas under the curve of cortisol released after transport and naloxone + transport treatments were also compared by paired Student's $t$ test.

\section{Results}

All the cows remained acyclic during the period of investigation with plasma progesterone concentration $<0.5 \mathrm{ng} / \mathrm{ml}$ at each oestradiol treatment.

The characteristics of the oestradiol-induced LH surge in the control, the transported and the naloxone + transported cows are given in Table 1 . All the control cows had a normal LH surge. In the transported cows, the surge was significantly delayed, shortened, of reduced amplitude and had a reduced area under the curve $(P<0.05-P<0.01)$ in 4 cows, and was totally blocked in the fifth. The LH surge in the naloxone + transported cows was also delayed and reduced in 3 cows and was totally blocked in the other 2 . The characteristics of the LH surges in the transport and naloxone + transport groups were not different $(P>0.05)$.

Table 1. Characteristics of the LH surge in response to oestradiol in control, transported ( $30 \mathrm{~min})$, and naloxone $(250 \mathrm{mg})+$ transport-treated cows in the early post-partum period

\begin{tabular}{lccccc}
\hline Treatment & $\begin{array}{c}\text { Total no. } \\
\text { of cows }\end{array}$ & $\begin{array}{c}\text { Onset (h) after } \\
\text { oestradiol }\end{array}$ & $\begin{array}{c}\text { Duration } \\
(\mathrm{h})\end{array}$ & $\begin{array}{c}\text { Peak conc. } \\
(\mathrm{ng} / \mathrm{ml})\end{array}$ & $\begin{array}{c}\text { Area under the curve } \\
\text { (Arbitrary Units) }\end{array}$ \\
\hline Control & 4 & $18 \cdot 0 \pm 2 \cdot 8$ & $7 \cdot 0 \pm 1 \cdot 2$ & $64 \cdot 7 \pm 17 \cdot 1$ & $52 \cdot 2 \pm 8 \cdot 1$ \\
Transport & $5 \dagger$ & $23 \cdot 5 \pm 3 \cdot 4^{*}$ & $3 \cdot 5 \pm 1 \cdot 0^{* *}$ & $35 \cdot 0 \pm 10 \cdot 9^{*}$ & $24 \cdot 4 \pm 11 \cdot 3^{* *}$ \\
$\begin{array}{l}\text { Naloxone }+ \\
\text { transport }\end{array}$ & $5 \ddagger$ & $23 \cdot 3 \pm 5 \cdot 8$ & $3 \cdot 3 \pm 1 \cdot 2^{* *}$ & $26 \cdot 7 \pm 4 \cdot 9^{*}$ & $15 \cdot 3 \pm 4 \cdot 7^{* * *}$ \\
\hline
\end{tabular}

Values are mean \pm s.d.

${ }^{*} P<0.05 ; * * P<0.01 ; * * * P<0.001$, compared with the control values.

†One cow did not produce an LH surge and values are not included.

$\ddagger$ Two cows did not produce an LH surge and values are not included.

All cows released cortisol in response to transport (Fig. 1). The peak cortisol concentration occurred $30-45 \mathrm{~min}$ after the start of the journey. The mean peak concentration was $4.4 \pm 1.8$ times higher than the pretreatment cortisol concentration in the transported cows and $5.4 \pm 2.0$ 
times higher in the naloxone + transported cows. The area under the cortisol curve was significantly higher $(P<0.001)$ after naloxone + transport $(58.0 \pm 14.0$ units $)$ than after transport alone $(32 \cdot 0 \pm 5 \cdot 3$ units $)$.

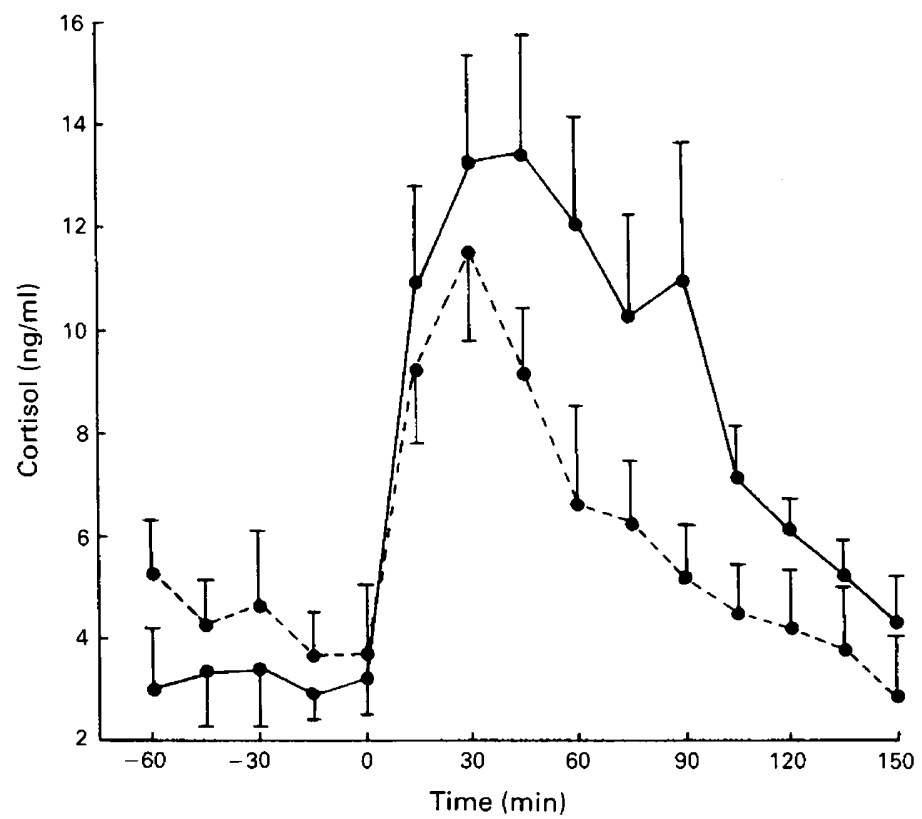

Fig. 1. Plasma cortisol concentrations (mean \pm s.e.m.) in 5 cows in response to $30 \mathrm{~min}$ transport alone $(---)$ ) or simultaneously with $250 \mathrm{mg}$ naloxone i.v. (- Naloxone was injected and transport began at time 0 .

\section{Discussion}

All the transported cows had an abnormal LH surge in response to oestradiol, confirming earlier results (Nanda et al., 1988a). Administration of naloxone at the onset of transport did not avert the detrimental effects of transport. In fact, more cows failed to release an LH surge and even the responding cows released a reduced amount of $\mathrm{LH}$ after naloxone + transport than after transport alone. Although it could not be proved statistically because of the low number of animals, naloxone appeared to have added to the stressful effects of transport on $\mathrm{LH}$ release. Unlike unstressed rats (Allen \& Kalra, 1986), naloxone failed to advance the onset of the LH surge in the transported cows.

Transport alone increased the release of cortisol in cows, as reported by Dobson (1987) and Mitchell et al. (1988). Incorporation of naloxone with transport further stimulated the release of cortisol beyond that of transport alone. Naloxone alone elevated cortisol concentrations in cows, to an extent directly proportional to the pre-treatment cortisol concentrations (Nanda et al., 1989) suggesting that naloxone augments stress-induced cortisol release. Similar studies on farm animals are not available for comparison, but ACTH and corticosterone were greater after photic or audiogenic stress in naloxone-injected rats compared to saline-treated controls (Siegel et al., 1982). On the other hand, both morphine and naloxone prevented elevation of plasma corticosteroids in response to ether stress in rats (Gibson et al., 1979). The difference in the effects of naloxone may be due to the different types of opioid receptors involved. Moreover, opioid regulation of cortisol in 
rats is unlike that of cows; cortisol concentrations are suppressed by opioid agonists in cows (Nanda et al., 1989), but elevated in rats (Grossman \& Rees, 1983).

An opioidergic system is actively involved in the regulation of LH release in early post-partum cows as revealed by increased LH responses to naloxone (Whisnant et al., 1986; Cross et al., 1987). There are also high opioid receptor concentrations in parts of the brain known to release Gn RH (Trout \& Malven, 1988). If stress were opioid-mediated, naloxone would be expected to counteract the suppressive effects of stress on the LH surge. The inability of naloxone to do so may therefore disprove our hypothesis. However, this conclusion may not be true. Apart from the effects of naloxone on the GnRH-related opioids, naloxone also affects the release of cortisol. Since ACTH is co-secreted with $\beta$-endorphin (Guillemin et al., 1977) from a common precursor, pro-opiomelanocortin (Imura et al., 1983), an increase in cortisol may reflect an exaggerated increase in the $\beta$-endorphin concentration after treatment with naloxone as well as transportation. This may explain the tendency to further suppression of oestradiol-induced LH surges by naloxone in the transported cows.

Plasma concentrations of $\beta$-endorphin increase after acute physical stress to cows (Shutt $\&$ Fell, 1988). A temporal relationship has been reported between a rise in plasma $\beta$-endorphin and suppression in the tonic $\mathbf{L H}$ release in sheep in response to isolation and confinement (Malven, 1987), E. coli bacteraemia (Leshin \& Malven, 1984) or acupuncture (Malven et al., 1984). Treatment with naloxone failed to relieve the LH suppression in these, situations. Naloxone also failed to induce LH release in cows with increased plasma cortisol concentrations (Gregg et al., 1986; Whisnant et al., 1986).

The release of $\beta$-endorphin is in part regulated by its own negative feedback mechanism (Carr et al., 1982), which may be interrupted by the receptor antagonist, naloxone. A continuing stressor (transport) and a lack of negative feedback may explain the (suspected) increase in $\beta$-endorphin (as reflected by cortisol release). The further stimulation of the hypothalamo-pituitary-adrenal axis, which may have implications for LH release, rendered this model unfit to study our hypothesis. A lack of improvement in LH release after naloxone in stressful situations may not, however, be interpreted as an exclusion of opioid involvement.

In conclusion, naloxone failed to avert the detrimental effects of transport stress on oestradiolinduced LH surge. However, this may not disprove our hypothesis that stress suppresses LH through opioids, because naloxone given to transported cows appeared to aggravate further the release of opioids as reflected by the increased cortisol release.

We thank the Association of Commonwealth Universities, London, and the University of Liverpool for financial support; NIAMDK, Dr L. E. Reichert and Dr F. J. Cunningham for LH assay reagents; David Horne for care of cows; and Hilary Pursell for technical assistance.

\section{References}

Alam, M.G.S. \& Dobson, H. (1986) Effect of various veterinary procedures on plasma concentrations of cortisol, luteinising hormone and prostaglandin $\mathbf{F}_{2 a}$ metabolite in the cow. Vet. Rec. 118, 7-10.

Alam, M.G.S., Dobson, H. \& Fitzpatrick, R.J. (1986) Endocrine response to different doses of ACTH in cows. Br. vet. J. 142, 239-244.

Allen, L.G. \& Kalra, S.P. (1986) Evidence that a decrease in opioid tone may evoke preovulatory luteinizing hormone release in the rat. Endocrinology 118, 2375-2381.

Bernard, K., Patricia, P., Veronique, L., Alain, S., Florence, G., Marie-Claire, L., Miklos, P., Catherine, B. \& Robert, S. (1988) Interactions between $17 \beta$-estradiol and the hypothalamo-pituitary $\beta$-endorphin system in the regulation of the cyclic $\mathrm{LH}$ secretion. J. Steroid Biochem. 30, 161-168.

Brooks, A.N., Lamming, G.E., Lees, P.D. \& Haynes, N.B. (1986) Opioid modulation of LH secretion in the ewe. J. Reprod. Fert. 76, 693-708.

Carr, D.B., Bergland, R., Hamilton, A., Blume, H., Kasting, N., Arnold, M., Martin, J.B. \& Rosenblatt, M. (1982) Endotoxin-stimulated opioid peptide secretion: two secretory pools and feedback control in vivo. Science, $N Y 217,845-848$.

Cross, J.C., Rutter, L.M. \& Manns, J.G. (1987) Effects of progesterone and weaning on $\mathrm{LH}$ and FSH responses to naloxone in postpartum beef cows. Dom. Anim. Endocrinol. 4, 111-122. 
Dobson, H. (1987) Effect of transport stress on luteinizing hormone released by $\mathrm{GnRH}$ in dairy cows. Acta endocr., Copenh. 115, 63-66.

Echternkamp, S.E. (1984) Relationship between LH and cortisol in acutely stressed beef cows. Theriogenology 22, 305-311.

Gibson, A., Gisburg, M., Hall, M. \& Hart, S.L. (1979) The effects of opioid receptor agonists and antagonists on the stress-induced secretion of corticosterone in mice. Br. J. Pharmac. 65, 139-146.

Gregg, D.W., Moss, G.E., Hudgens, R.E. \& Malven, P.V. (1986) Endogenous opioid modulation of luteinizing hormone and prolactin secretion in postpartum ewes and cows. J. Anim. Sci. 63, 838-847.

Grossman, A. \& Rees, L.H. (1983) The neuroendocrinology of opioid peptides. Br. med. Bull. 39, 83-88.

Guillemin, R., Vargo, T., Rossier, J., Minick, S., Ling, N., Rivier, C., Vale, W. \& Bloom, F. (1977) $\beta$-endorphin and adrenocorticotropin are secreted concomitantly by the pituitary gland. Science, NY 197, 1367-1369.

Ieiri, T., Chen, H.T., Campbell, G.A. \& Meites, J. (1980) Effects of naloxone and morphine on the pro-estrous surge of prolactin and gonadotropins in the rat. Endocrinology 106, 1568-1570.

Imura, H., Nakai, K., Nakao, K., Oki, S., Tanaka, I., Jingami, H., Yoshimasa, T., Tsukada, T., Ikeda, Y., Suda, M. \& Sakamoto, M. (1983) Biosynthesis and distribution of opioid peptides. J. Endocr. Invest. 6, 139-149.

Kanchev, L.N., Dobson, H., Ward, W.R. \& Fitzpatrick, R.J. (1976) Concentrations of steroids in bovine peripheral plasma during the oestrous cycle and the effect of betamethasone treatment. J. Reprod. Fert. 48, 341-345.

Kesler, D.J., Garverick, H.A., Bierschwal, C.J., Elmore, R.G. \& Youngquist, R.S. (1979) Reproductive hormones associated with normal and abnormal changes in ovarian follicles in postpartum dairy cows. $J$. Dairy Sci. 62, 1290-1296.

Leshin, L.S. \& Malven, P.V. (1984) Bacteria-induced changes in pituitary hormone release and effect of naloxone. Am. J. Physiol. 247 (Endocrinol. Metab. 10), E585-E591.

Malven, P.V. (1987) Searching for an inhibitory action of blood-borne $\beta$-endorphin on LH release. J. Reprod. Fert., Suppl. 34, 9-16.

Malven, P.V., Bossut, D.F.B. \& Diekman, M.A. (1984) Effects of naloxone and electro-acupuncture treatment on plasma concentrations of $\mathbf{L H}$ in sheep. $J$. Endocr. 101, 75-80.
Mitchell, G., Hattingh, J. \& Ganhao, M. (1988) Stress in cattle assessed after handling, after transport and after slaughter. Vet. Rec. 123, 201-205.

Nadaraja, R. \& Hansel, W. (1976) Hormonal changes associated with experimentally produced cystic ovaries in the cow. J. Reprod. Fert. 47, 203-208.

Nanda, A.S., Ward, W.R. \& Dobson, H. (1988a) Effect of transportation stress on the oestradiol-induced luteinising hormone release in dairy cows. Proc. 11th Int. Congr. Anim. Reprod. \& A.I., Dublin, Vol. II, 52, abstr.

Nanda, A.S., Ward, W.R. \& Dobson, H. (1988b) Opioid modulation of oestradiol-induced LH surge in dairy cows. J. Reprod. Fert., Abstr. Ser. 1, Abstr. 54.

Nanda, A.S., Dobson, H. \& Ward, W.R. (1989) Opioid modulation of the hypothalamo-pituitary-adrenal axis in dairy cows. J. Endocr. Invest. 12 (Suppl. 2), 34, abstr.

Radford, H.M., Nancarrow, C.D. \& Mattner, P.E. (1978) Ovarian function in suckling and non-suckling beef cows postpartum. J. Reprod. Fert. 54, 49-56.

Refsal, K.R., Jarrin-Maldonade, J.H. \& Nachreiner, R.F. (1988) Basal and estradiol-induced release of gonadotropins in dairy cows with naturally occurring ovarian cysts. Theriogenology 30, 679-693.

Sarkar, D.K. \& Yen, S.S.C. (1985) Changes in $\beta$ endorphin-like immunoreactivity in pituitary portal blood during the estrous cycle and after ovariectomy in rats. Endocrinology 116, 2075-2079.

Short, R.E., Randel, R.D., Staigmiller, R.B. \& Bellows, R.A. (1979) Factors affecting oestrogen-induced LH release in the cow. Biol. Reprod. 21, 683-689.

Shutt, D.A. \& Fell, L.R. (1988) The role of endorphins in the response to stress in sheep and cattle. Proc. Aust. Soc. Anim. Prod. 17, 338-341.

Siegel, R.A., Chowers, I., Conforti, N., Feldman, S. \& Weidenfeld, J. (1982) Effects of naloxone on basal and stress-induced ACTH and corticosterone secretion in the male rat-site and mechanism of action. Brain Res. 249, 103-109.

Trout, W.E. \& Malven, P.V. (1988) Quantification of naloxone binding sites in brains from suckled beef cows during post-partum anestrus and resumption of estrous cycles. J. Anim. Sci. 66, 954-960.

Whisnant, C.S., Thompson, F.N., Kiser, T.E. \& Barb, C.R. (1986) Effect of naloxone on serum luteinizing hormone, cortisol and prolactin concentrations in anestrous beef cows. J. Anim. Sci. 62, 1340-1345.

Received 17 April 1989 